Accounting and Management Information Systems

Vol. 19, No. 4, pp. 759-777, 2020

DOI: http://dx.doi.org/10.24818/jamis.2020.04006

\title{
Are controlled companies underperforming?
}

\author{
Linh $\mathrm{Le}^{1, \mathrm{a}}$ and Dongfang $\mathrm{Nie}^{\mathrm{b}}$
}

${ }^{a}$ Penn State Behrend, USA

${ }^{\mathrm{b}}$ University of Texas Permian Basin, USA

\begin{abstract}
Research Question: Are controlled companies underperforming in the United States?

Motivation: Anecdotal evidence shows that the average market capitalization of controlled firms increased from $\$ 8.3$ billion in 2005 to $\$ 20.6$ billion in 2015 . Given the rapid increase in capitalization, the group of controlled companies has become an important player in the US capital market. However, little is known about controlled companies.

Idea: We examine whether controlled companies are underperforming relative to noncontrolled companies in the United States.

Data: The data sample consists of 351 listed companies in the United States for the fiscal year 2014.

Tools: 176 controlled companies were manually collected by performing the keyword search "controlled company" from the U.S. Securities and Exchange Commissions (SEC) website via "www.seekedgar.com/". Specifically, we search "controlled company" from proxy statement DEF 14A. Each controlled company is verified after reading through the proxy statement.

Findings: Using 176 controlled companies and 176 random sampled non-controlled companies, we find that controlled companies are underperforming compared to noncontrolled companies.

Contribution: To the best of our knowledge, we are the first to collect the group of controlled companies in the US and we are among the first to study how firm performs under the type II agency problem (Pantzalis et al. 1998). We contribute to the stream of literature on how ownership structure (e.g., family-controlled firms) affects firm performance (Anderson \& Reeb, 2003). Consistent with the findings from family-controlled firms, we show that ownership structure affects firm performance. Out study sheds light on the important role of controlled companies in the US capital market.
\end{abstract}

Keywords: controlled companies, financial performance, ownership structure

JEL codes: $\mathrm{M} 410$

\footnotetext{
${ }^{1}$ Corresponding author: School of Business, Penn State Behrend 214 burke center erie, PA 16563, email addresses: 1z15502@ psu.edu
} 


\section{Introduction}

According to the National Association of Securities Dealers Automated Quotation System (NASDAQ) definition, a controlled company is "a company of which more than $50 \%$ of the voting power for the section of directors is held by an individual, a group or another company". These firms have a unique structure in that they may opt-out of the independent director requirements that apply to the rest of the public firms. For instance, they are not required to have a majority independent board of directors, nominating, or compensation committee. Some examples of controlled companies are Google, Berkshire Hathaway, and Facebook. Facebook founder Mark Zuckerberg controls 60.1 percent of the voting power of Facebook in 2015. Co-founders of Google Inc. own 54.3 percent of the voting power. Understanding the financial performance of controlled companies is important to investors and policymakers because recent studies reveal that controlled company grows tremendously. For example, according to the 2016 Controlled Company Review of Performance and Risk, the average market capitalization of controlled firms increased from $\$ 8.3$ billion in 2005 to $\$ 20.6$ billion in 2015 . Overall, the market capitalization growth rate of controlled companies was higher than that of the noncontrolled companies (IRRC Institute, 2016). In this study, we examine whether controlled companies are underperforming relative to non-controlled firms in the United States.

Prior studies find that corporate governance structures affect firm outcomes (e.g., Chen et al., 2008; Cheng, 2014; Cremers et al., 2017). The same logic applies to controlled companies. On the one hand, minority shareholders may be at disadvantage due to the lack of control in companies they invest in. That's because controlling power allows entrenching directors and managers to inappropriately allocate resources for personal gains i.e., shirking, empire-building, and private rent extraction (Jensen, 1988; Cremers et al., 2017). As a result, these deteriorating behaviors may negatively affect firms' financial performance. On the other hand, power concentration in controlling shareholders release managers from short-term market pressure to meet or beat earnings targets. Consequently, the controlled company structure makes managers commit to longer-term promising projects and reduce overinvesting in short-term ones. As a result, controlled companies can potentially outperform their non-controlled counterparts. Therefore, it is unclear whether controlled companies outperform non-controlled companies.

We hand-collect the list of controlled companies from the United States Securities and Exchange Commission's website in 2014. In particular, we search for the keyword "controlled company" in all proxy statements and verify the list of controlled companies by reading all proxy statements contain the keyword. We randomly select our non-controlled company sample from the COMPUSTAT population. We present a random sample rather than a matched sample for a few 
reasons. First, random sampling generates a random sample which mitigates the selfselection problem. Second, given the fact that controlled firms have larger size and revenue (as figure 2 shows) than non-controlled firms, random sampling generates a list of firms with smaller size. If controlled companies underperform the list of smallsize non-controlled companies, the results will be more pronounced when using a size-matched sample. To address our research question, we regress the industryadjusted Return on Assets (ROA) measure on a dummy variable which equals to one if a firm $\mathrm{i}$ is a controlled company and zero otherwise. Our findings indicate that controlled companies are underperforming compared to non-controlled companies in our sample.

The literature on controlling shareholder and ownership structure only examines the firm performance of blockholders or family-controlled firms (Ali et al., 2007; Fan \& Wong, 2002; Francis et al., 2005; Lin et al., 2011). ${ }^{1,2}$ This paper extends this line of literature to investigate the association between the status of controlled companies and firm performance. This paper extends the existing literature in that it is the first study to investigate controlled companies in general. We contribute to the scarce literature about controlled firms. We also contribute to the agency theory literature by studying firm performance under a non-traditional agency framework (Hermalin \& Weisbach, 1991; IRRC, 2016)). The traditional agency framework suggests that owners' interest conflicts with that of managers. However, in a controlled company, the interest conflict is between the controlling party and the minority shareholders too. The special corporate governance structure in controlled firms creates a unique non-traditional agency framework. Using counterfactual reasoning, we indirectly test the advantages and disadvantages of weak corporate governance. For instance, we compute the economic significance of becoming a controlled company for a noncontrolled company. The findings could be informative to investors.

\section{Literature review}

\subsection{Background of controlled company}

Both the NYSE and the NASDAQ define a controlled company as one of which more than $50 \%$ of the voting power is held by a single person, entity, or group. A controlled company is not required to comply with Sections 802(a), 804 or 805 in the SOX (SEC, 2003). Section 802(a) states: "At least a majority of the directors on the Board of Directors of each listed company must be independent directors as defined in Section 803A, unless the issuer is a controlled company (see Section 801(a)), a Smaller Reporting Company (see Section 801(h)) or otherwise exempt under Section 801." Further, section 804 does not require a controlled company to have a nominating committee and executive compensation committee. 
The Sarbanes-Oxley Act of 2002 (SOX) required the majority of the board of directors of the audit committee and the board itself of a listed firm to be independent (SEC, 2002). However, both the NYSE and the NASDAQ recommended that a controlled company may opt for an exemption to this requirement of the majority of the board to be independent. If a controlled company chooses to take the exemption, the company needs to disclose the basis for the exemption and the corporate governance standards with which the company does not comply. ${ }^{3}$

Facebook's annual report states that: "Mr. Zuckerberg is entitled to vote his shares, and shares over which he has voting control as governed by a voting agreement, in his own interests, which may not always be in the interests of our stockholders generally." Facebook Inc's annual report discloses Zuckerberg's over 50\% voting power as a risk factor. ${ }^{4}$ Facebook is a controlled company and may rely on the "controlled company exemption" so that the firm does not need to meet certain corporate governance listing standards in the stock exchange. For instance, the majority of the board does not need to be independent, which reduces firm transparency (Armstrong et al., 2014). The special corporate governance structure in controlled firms creates a unique setting in which the agency framework does not apply. Agency theory suggests that owners' and managers' interests do not align with each other. However, in a controlled company, the interest conflict is not between the owner and the manager (the type I agency problem), but between the controlling party and the minority shareholders (the type II agency problem) (Pantzalis et al. 1998; Ben Ali et al., 2020). Therefore, a controlled company provides a unique setting to study how corporate governance structure affects firm performance.

\subsection{Background of the recent development of controlled companies}

While most listed companies in the United States have dispersed shareholder structure (McGuire et al., 2014), controlled companies are becoming increasingly popular in recent years. In controlled companies, founders, family members, and institutional investors can own large blocks of shares that belong to the class of voting stock (Srinidhi et al., 2014). The number of controlled companies grows from 87 firms in the S\&P 500 in 2002 to 114 firms in the S\&P 500 in 2012 (IRRC Institute, 2012). Since 2012, the number of controlled firms in the S\&P 500 decreases by approximately eight percent (Kamonjoh, 2016). Figure 1 shows the concentration of controlled companies by industry. About $69 \%$ of all controlled companies concentrate in three industry sectors. As seen in figure 2, controlled companies have 1 -year and 3-years average revenue higher than non-controlled companies. One example of the controlled companies, Wal-Mart, has revenue of $\$ 400$ billion on average from 2005 to 2015 (Kamonjoh, 2016). In terms of growth, the median market capitalization for controlled companies doubled in the ten years 2005-2015. The average controlled company market capitalization grew from $\$ 8.3$ billion in 2005 to $\$ 20.6$ billion in 2015 . Overall, the descriptive statistics of controlled 
companies suggest that controlled companies seem to grow in terms of numbers and revenue in the United States.

Figure 1. Controlled companies by Industry sector

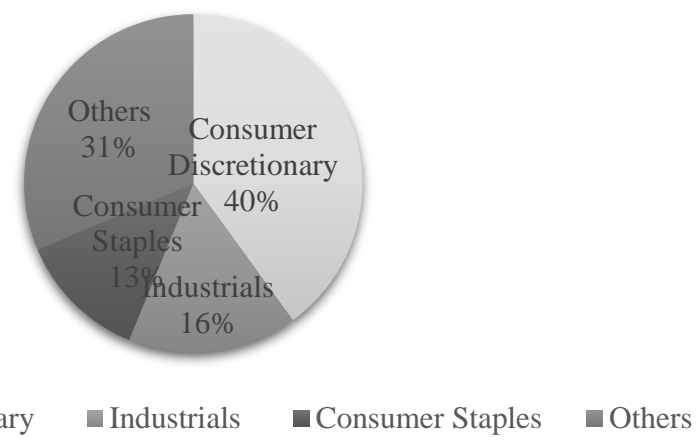

(Data Source: IRRC Institute report 2015)

Figure 2. Average revenue of controlled vs. non-controlled companies 2005-2015 (in millions)

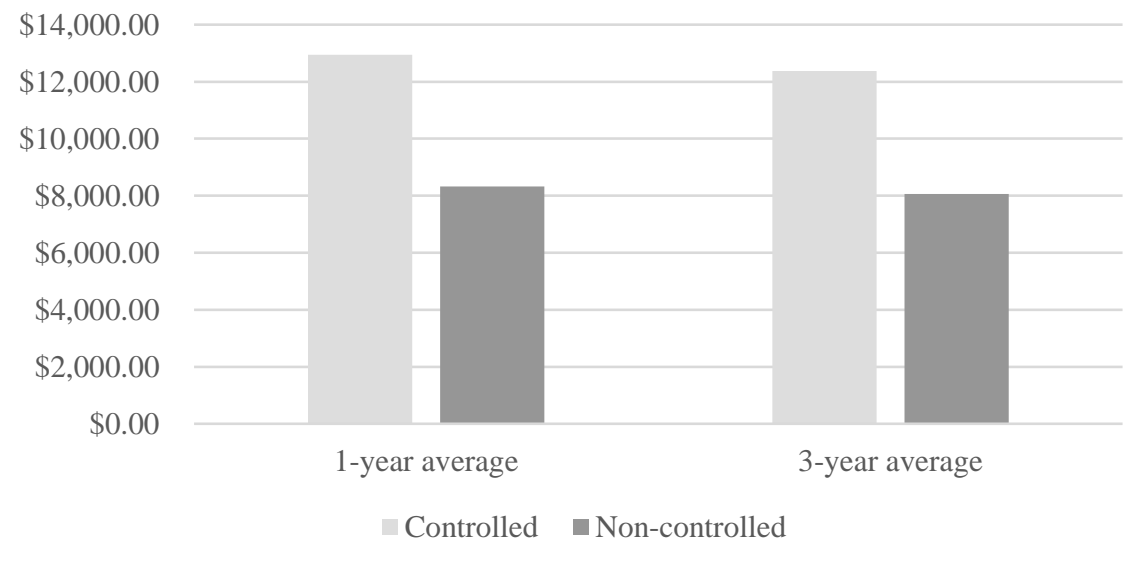

(Data Source: IRRC Institute Report 2015)

\subsection{Literature review on the ownership structure}

A majority of U.S. companies have a dispersed shareholder structure which involves the separation of owners and managers in managing companies. Jensen and Meckling (1976) point out potential conflicts of interest between managers and owners, called agency problem. While owners want to maximize their companies' value, managers may be only interested in their compensation package. As a result, managers may primarily focus on the short-term increase in firm financial 
performance while potentially damaging long-term firm financial performance. Owners or shareholders address this agency problem by introducing some monitoring mechanisms. However, in most companies with dispersed shareholder structure, shareholders may not have sufficient information and strong incentives to allocate their personal resources to monitor managers. In theory, shareholders have a diversified portfolio so that one company's shares may account for a small portion of the whole portfolio. In contrast, controlling shareholders in controlled companies have a large block of shares allocated to one company. They are likely to have a bigger stake that induces strong incentives to monitor managers. Thus, agency conflicts can be mitigated in controlled companies, increasing firm performance in the long run (Andres, 2008). Conventional wisdom also suggests that controlling shareholders encourage innovation and speedy decision-making, two drivers of firm value creation (Kamonjoh, 2016).

There is a potential drawback of concentrated shareholder structure in controlled companies. Although agency conflicts between managers and shareholders can be reduced, conflicts of interest between controlling shareholders and minority shareholders can be present. Controlling shareholders may use their power to maximize their utility, which may not necessarily result in maximizing utility for all shareholders. They can transfer their companies' resources to themselves or to other companies that they control (Andres, 2008). Controlling shareholders can also engage in risky behaviors that destroy firm value (Kamonjoh, 2016). Overall, it is unclear whether the presence of controlling shareholders will lead to better financial performance theoretically.

\subsection{The relation between controlled companies and financial performance}

Since there is no previous study about the relation between controlled companies and financial performance, we review the prior literature on family-controlled firms to form a general prediction regarding the financial performance of controlled firms. Anderson and Reeb (2003) examine family-controlled firms in the S\&P 500 and find that family-controlled firms perform better than non-family control firms. Miller $e t$ al. (2007) support Anderson and Reeb (2003)'s study by examining Fortune 1000 firms and a random sample of 100 small public firms. They also control for endogeneity and sample selection bias problems that may exist in previous studies. Another study finds that family-controlled firms are shown to be common in large, publicly-traded firms and generally have a lower cost of debt financing (Anderson \& Reeb, 2003). This finding suggests that family-controlled firms are viewed favorably by debtholders. Providing further evidence about the relation between family-controlled firms and financial performance, Villalongaa and Amitb (2006) find that family-controlled firms create value only when founders serve as CEO of the companies or as Chairman with a hired CEO. They use a sample of Fortune 500 firms to test their regression model. In other countries, Andres (2008) finds that family-controlled firms are more profitable than widely-held firms using panel data 
on 275 German exchange-listed companies. However, the finding is limited to companies that the founding family is still active either on the executive or the supervisory board. Thus, the result suggests that family-controlled firms perform better than non-family-controlled firms only under certain conditions. Recently, Isakov and Weisskopf (2014) document that family-controlled firms are generally more profitable than widely-held firms using a sample of Swiss listed firms from 2003 to 2010.

Although empirical evidence about the relation between family-controlled firms and financial performance suggests that controlled companies are likely to outperform non-controlled companies, family-controlled firms are only a subset of controlled companies. There are differences between family-controlled firms and other types of controlled firms, which may suggest that the result may not hold using a sample of controlled companies. Family members tend to stay in a company long enough to have the firm-specific knowledge or market-specific knowledge, helping them to manage and control the company better than short-term controlling shareholders and managers. In addition, the long-term nature of family shareholdings helps a family member to build a strong relationship with suppliers and other stakeholders (Andres, 2008). This can also contribute to better financial performance. Other types of controlled companies involving institutional investors ${ }^{5}$ and founders may not share similar characteristics as family-controlled firms. Institutional investors may not have firm-specific knowledge while founders may not have long-term experience to manage the company.

\section{Research design}

\subsection{Data and sample selection}

The data sample consists of 351 listed companies in the United States for the fiscal year 2014. 176 controlled companies were manually collected by performing the keyword search "controlled company" from the U.S. Securities and Exchange Commissions (SEC) website via "www.seekedgar.com/". Specifically, we search "controlled company" from proxy statement DEF 14A. Each controlled company is verified after reading through the proxy statement. For instance, for the controlled company "Aramark" in Appendix A, we read its DEF 14A and confirm that it is a controlled company because it states that:

"We utilize certain of these exemptions and have not determined that we have a majority of independent directors on the Board, and have not determined that we have a nominating and corporate governance committee or a compensation committee that is composed entirely of independent directors. Accordingly, you do not have the same protections afforded to stockholders of companies that are subject to all of the NYSE corporate governance requirements. In the event that we cease to be a "controlled company," we will be required to comply with these provisions within the transition 
periods specified in the NYSE corporate governance rules." (Source: Arrmark's DEF 14 A-proxy statement)

176 non-controlled companies were randomly selected from the Compustat population. One non-controlled company was deleted from the sample due to missing available financial information in Compustat. We only collect one year of data due to time constraints. Compustat databases can be accessed through Wharton Research Data Service (WRDS). The database provides financial information for all listed companies in the United States. Since controlled companies are relatively small compared to non-controlled companies, not all non-controlled companies were included in the data sample. ${ }^{6}$

\subsection{Dependent variable}

Prior literature has used returns on assets (ROA) to measure firm financial performance (Andres, 2008; Isakov \& Weisskopf, 2014). We follow existing literature using ROA as the main dependent variable in the study. $\mathrm{ROA}_{\mathrm{i}}$ is defined as a binary variable which takes on the value of one if company "i" has ROA equal to or greater than its industry median ROA, and zero otherwise. As shown in table $1,55.3 \%$ of 351 firms in the data sample have ROA above the industry median's while $44.7 \%$ have ROA below the industry median. Table 2 - Panel A presents summary statistics for the variable $R O A_{i}$. It is interesting to note that more than half of the firms in the sample have ROA above their industry median's, indicating that the data sample is a good representative of the whole Compustat population. Table 2- Panel $\mathrm{B}$ and $\mathrm{C}$ also give additional information about the variable $R O A$ for noncontrolled firms and controlled firms. The ROA of controlled firms is lower than that of non-controlled firms. However, the univariate test in table 3 does not show a significant difference between ROA of controlled firms and that of non-controlled firms. We will rely on a multivariate test to draw our conclusion, after including relevant control variables.

Table 1. Frequency table of the dependent variable $R O A$

\begin{tabular}{lll}
\hline $\mathbf{R O A}_{\mathbf{i}}$ & Frequency & Percent \\
\hline 0 & 157 & $44.7 \%$ \\
1 & 194 & $55.3 \%$ \\
Total & 351 & $100 \%$ \\
\hline
\end{tabular}

Table 2. T-Test

\begin{tabular}{lccccc}
\hline & Total & Control $=\mathbf{0}$ & Control $=\mathbf{1}$ & Difference & T- stats \\
\hline ROA & 0.554 & 0.593 & 0.514 & 0.0789 & $(1.49)$ \\
SIZE & 6.590 & 6.179 & 7.007 & $-0.829^{* * *}$ & $(-3.15)$
\end{tabular}




\begin{tabular}{lccccc}
\hline & Total & Control = 0 & Control = 1 & Difference & T- stats \\
\hline INVESTMENT & 0.231 & 0.214 & 0.249 & -0.0348 & $(-0.31)$ \\
GROWTH & 0.884 & 1.417 & 0.346 & 1.071 & $(0.91)$ \\
DIVIDEND & 0.014 & 0.025 & 0.002 & 0.0229 & $(1.28)$ \\
AGE & 3.185 & 3.191 & 3.179 & 0.0113 & $(0.11)$ \\
LEVERAGE & 0.351 & 0.250 & 0.452 & $-0.202^{* * *}$ & $(-3.69)$ \\
\hline
\end{tabular}

$*, * *$, and $* * *$ indicates significant level at $10 \%, 5 \%$ and $1 \%$ respectively

\subsection{Independent variable and control variables}

The goal of this paper is to determine whether controlled companies are underperforming relative to non-controlled companies. We rely on prior literature and logical reasoning to choose a set of independent variables. Our main independent variable of interest is CONTROL. It is unclear whether controlled companies underperform or overperform their counterparts since there are theoretical arguments on both sides. On the one hand, if the mitigated agency problem in controlled companies has a dominating effect on firm financial performance, the coefficient of CONTROL is expected to be positive. On the other hand, if the misappropriate of firm resources by controlling shareholders has a greater impact on firm financial performance, the coefficient of CONTROL is expected to be negative. Nevertheless, several studies (Anderson \& Reeb, 2003; Andres, 2008; Isakov \& Weisskopf, 2014; Miller et al., 2007) and document that family-controlled firms are generally more profitable than non-family controlled firms, therefore we expect that controlled firms also perform better than non-controlled firms financially.

Firm size has been shown to be related to firm financial performance (Andres, 2008; Isakov \& Weisskopf, 2014). Firm size can improve a firm's ability to maintain competitive advantage through economies of scale, economies of scope, and learning effect (Roberts \& Dowling, 2002). Therefore, a bigger firm size implies more available resources to produce goods and to invest in a marketing campaign. Thus, we include firm size (denoted SIZE) as one of the control variables. We expect the effect of firm size on firm financial performance to be positive. Companies can spend millions of dollars on research and development (R\&D) programs to produce innovative products in order to gain a competitive advantage in the market. While investment programs can help firms generate a future stream of revenues, it may incur a high cost at the current period. High level of investment intensity in a company can result in a large amount of research and development expense, depressing its profit in the current period. Therefore, we include the amount of capital expenditure that company "i" incurs for the current period scaled by net sales (denoted INVESTMENT) in the model. Capon et al. (2011) summarize studies on financial performance and document that capital investment intensity is positively 
associated with financial performance at the industry level but negatively associates with financial performance at the firm level. We expect a similar effect of investment intensity on firm financial performance.

Growth in sales is another factor frequently mentioned in research studying financial performance. Growth is related to higher financial performance. However, there can be a negative consequence of excessive growth. As a company grows rapidly, high demand for sales can result in a temporarily inadequate supply of resources to support excessive growth. Thus, a company may suffer low income in the current period due to excessive growth. Therefore, we include a one-year percentage change in sales of company "i" (denoted GROWTH) in the model. The effect of growth in sales on financial performance can be either negative or positive, depending on whether company "i" has excessive growth or not.

Dividends can be another factor affecting financial performance. Companies tend to pay dividends when they have positive earnings in the current period. For instance, Andres (2008) includes dividends in his model to study the financial performance of family-controlled companies. Thus, the amount of dividend paid to common shareholders of company "i" scaled by the book value of equity (denoted DIVIDEND) is included in our model as a control variable. We expect the coefficient of DIVIDEND to be positive.

Taking a high level of debt can lead to financial distress. Research has shown that financial distress negatively influences firm financial performance (Opler \& Titman, 1994). Firms with a high level of leverage can incur large interest expenses and a higher interest rate. This weakens firms' financial conditions and encourages their competitors to act aggressively to gain market shares. In addition, capital suppliers and other stakeholders are also concerned about financially distressed firms because these firms may default and go bankrupt. Therefore, we include the leverage ratio of company "i", computed as total debts divided by total assets (denoted LEVERAGE) in the model. Since distressed firms have been shown to perform poorly in prior literature, we expect the variable LEVERAGE has a negative coefficient (Opler \& Titman, 1994; Altman, 2000; Capon et al., 2011).

Studies on the financial performance of family-controlled firms include firm age as a control variable. This is because as firms grow, they gain industry- and marketspecific knowledge. This knowledge helps firms gain a competitive advantage in the market, hence generating positive earnings. Prior studies have documented a positive effect of firm age on firm financial performance (Andres, 2008; Isakov \& Weisskopf, 2014). We include a natural logarithm of firm age (denoted $A G E$ ) in the model and expect it to have a positive effect on financial performance. All variable descriptions and data sources are presented in Appendix A. 
We use the below model to test whether controlled firms underperform using noncontrolled firms as a control group. We are interested in the sign of the coefficient of CONTROL. A significant and negative $\beta_{2}$ suggests that controlled firms underperform relative to non-controlled firms, and vice versa.

$$
\begin{aligned}
& \text { ROA }_{\mathrm{i}}^{*}=\beta_{1}+\beta_{2} \text { CONTROL }_{\mathrm{i}}+\beta_{3} \text { SIZE }_{\mathrm{i}}+\beta_{4} \text { INVESTMENT }_{\mathrm{i}}+ \\
& \beta_{5} \text { GROWTH }_{\mathrm{i}}+\beta_{6} \text { DIVIDEND }_{\mathrm{i}}+\beta_{7} \text { AGE }_{\mathrm{i}}+\beta_{8} \text { LEVERAGE }_{\mathrm{i}}+\varepsilon_{\mathrm{i}}
\end{aligned}
$$

We do not use the raw return on assets as our dependent variable, but code ROA as a binary variable. ${ }^{7}$ The choice of independent and control variables in the model are based on prior literature and intuitive reasoning discussed in the above section.

\section{Empirical results}

\subsection{Descriptive statistics}

Table 2 provides summary statistics for the independent and control variables in the model. The minimum and maximum of the binary variable CONTROL are zero and one, respectively. This shows that this variable has been properly recorded in the data sample. Since the variable SIZE is measured by taking the natural logarithm of total assets for each company, firms in our sample have approximately 720 million dollars in total assets on average. ${ }^{8}$ It seems that firms in the sample have a reasonable size as a big firm such as Coca-Cola has approximately 87 billion dollars in total assets. For every one dollar of net sales, firms take 23 cents to invest in machines, building, research, and development (R\&D) programs on average. In other words, firms spend more than $20 \%$ of their revenues on investments. It shows that firms focus on reinvesting income in programs that may generate profit in the future period while paying dividends. For every one dollar of equity, firms pay about 1.4 cents of dividends back to shareholders on average. This is reasonable for mature firms as the average firm age in the sample is approximately 24 years old. ${ }^{9}$ The firm age in our sample varies from one to 176 years. The growth rate of sales varies greatly from $-87 \%$ to $20700 \%$. As the maximum growth rate in sales does not seem to be reasonable, we check the data and confirm that one company has increased sales from $\$ 2000$ in 2013 to $\$ 416$ thousand in 2014 . The average growth rate in sales is $89 \%$. Therefore, half of the firms in our sample are growing in sales. In terms of financial leverage, $35 \%$ of total assets belong to their debtholders and approximately $65 \%$ of total assets belong to their shareholders. There may be some financially distressed firms in the sample as the maximum number of total debts to total assets is 7.14, meaning a firm has about seven dollars of debt per one dollar of total assets. 
Table 3. Summary statistics

Panel A. Summary statistics for independent variables, all observations

\begin{tabular}{lccccc} 
Variable name & $\begin{array}{c}\text { Number of } \\
\text { observations }\end{array}$ & Mean & $\begin{array}{c}\text { Standard } \\
\text { Deviation }\end{array}$ & Minimum & Maximum \\
\hline ROA & 351 & -0.16 & 1.02 & -15.14 & 0.33 \\
CONTROL & 351 & 0.50 & 0.50 & 0 & 1 \\
INVESTMENT & 351 & 0.23 & 1.05 & 0 & 15.32 \\
SIZE & 351 & 6.58 & 2.50 & -0.39 & 13.38 \\
GROWTH & 351 & 0.89 & 11.10 & -0.87 & 207 \\
DIVIDEND & 351 & 0.014 & 0.17 & -2.18 & 0.98 \\
AGE & 351 & 3.19 & 1.01 & 0 & 5.12 \\
LEVERAGE & 351 & 0.35 & 0.52 & 0 & 7.14 \\
\hline
\end{tabular}

Panel B. Summary statistics for independent variables for which CONTROL $_{i}=0$

\begin{tabular}{lccccc} 
Variable name & $\begin{array}{c}\text { Number of } \\
\text { observations }\end{array}$ & Mean & Standard Deviation & Minimum & Maximum \\
\hline ROA & 176 & -0.23 & 1.33 & -15.14 & 0.33 \\
CONTROL & 176 & 0 & 0 & 0 & 0 \\
INVESTMENT & 176 & 0.22 & 0.78 & 0 & 6.80 \\
SIZE & 176 & 6.16 & 2.72 & -0.391 & 13.38 \\
GROWTH & 176 & 1.43 & 15.62 & -.87 & 207 \\
DIVIDEND & 176 & 0.03 & 0.092 & 0 & 0.98 \\
AGE & 176 & 3.19 & 0.99 & 0 & 5.12 \\
LEVERAGE & 176 & 0.25 & 0.34 & 0 & 2.38 \\
\hline
\end{tabular}

$\underline{\text { Panel C. Summary statistics for independent variables for which } \text { CONTROL }_{i}=1}$

\begin{tabular}{lccccc}
\hline Variable name & $\begin{array}{c}\text { Number of } \\
\text { observations }\end{array}$ & Mean & Standard Deviation & Minimum & Maximum \\
\hline ROA & 175 & -0.84 & 0.57 & -6.68 & 0.24 \\
CONTROL & 175 & 1 & 0 & 1 & 1 \\
INVESTMENT & 175 & 0.25 & 1.26 & 0 & 15.32 \\
SIZE & 175 & 7.00 & 2.17 & 0.24 & 11.33 \\
GROWTH & 175 & 0.35 & 1.34 & -0.58 & 12.33 \\
DIVIDEND & 175 & 0.014 & 0.17 & -2.18 & 0.98 \\
AGE & 175 & 3.18 & 1.03 & 0 & 5.09 \\
LEVERAGE & 175 & 0.45 & 0.64 & 0 & 7.15 \\
\hline
\end{tabular}


Since we are interested in the financial performance of non-controlled vs. controlled firms, we generate separate statistics for non-controlled firms and controlled firms. Table2 - Panel B and C - present summary statistics for independent variables of non-controlled and controlled firms, respectively and table 3 shows t-test to evaluate whether the means of each variable are significantly different between noncontrolled and controlled firms. We note that the growth rate of sales of controlled and non-controlled firms are quite different. The average sales growth rate of noncontrolled firms is $143 \%$ while that of controlled firms is only $35 \%$. Controlled firms are more homogenous than non-controlled firms in terms of growth as the standard deviation of the sales growth rate of controlled firms is far less than that of noncontrolled firms. Non-controlled firms pay more dividends and have less debt than controlled firms. Non-controlled firms are larger than controlled firms. T-test results show that firm size and leverage are significantly different between the two groups of firms. Non-controlled firms appear to have less leverage and are generally smaller in size than their controlled counterparts. Overall, controlled and non-controlled firms show different characteristics, which may result in a difference in financial performance.

Table 4 presents the correlation matrix among variables. In particular, ROA positively correlates with SIZE, indicating that a larger firm tends to perform better financially. AGE also positively correlates with SIZE, suggesting that older firms have better financial performance than younger firms. And older firms have less amount of investment as AGE and INVESTMENT are negatively correlated. Since the coefficients show that all variables are not highly correlated, we are not concerned about the multicollinearity problem in this setting.

Table 4. Correlation matrix

\begin{tabular}{|c|c|c|c|c|c|c|c|c|}
\hline & ROA & CONTROL & SIZE & INVESTMENT & GROWTH & DIVIDEND & AGE & LEVERAGE \\
\hline ROA & 1.00 & & & & & & & \\
\hline CONTROL & -0.08 & 1.00 & & & & & & \\
\hline SIZE & $0.33^{* * *}$ & $0.17^{* s}$ & 1.00 & & & & & \\
\hline INVESTMENT & $-0.12^{*}$ & 0.02 & -0.03 & 1.00 & & & & \\
\hline GROWTH & -0.07 & -0.05 & $-0.15^{* *}$ & 0.04 & 1.00 & & & \\
\hline DIVIDEND & 0.01 & -0.07 & -0.02 & -0.00 & -0.00 & 1.00 & & \\
\hline AGE & $0.22^{* * *}$ & -0.01 & $0.26^{* * *}$ & $-0.22^{* * *}$ & -0.03 & -0.06 & 1.00 & \\
\hline LEVERAGE & $-0.12^{*}$ & $0.19^{* * *}$ & -0.02 & -0.04 & -0.04 & -0.08 & -0.03 & 1.00 \\
\hline
\end{tabular}

\subsection{Estimation results}

Table 5 presents the MLE estimation of the probit regression model. The main variable of interest, CONTROL, is significant at the 95\% level. Column 1 shows the probit regression without the main variable of interest CONTROL and column 2 shows the full probit model. Including CONTROL shows improvement in pseudo$\mathrm{R}$-squared of $13.6 \%$. The negative coefficient of CONTROL in column (2) implies that controlled companies underperform, relative to non-controlled firms. This contradicts prior literature on the financial performance of family-controlled companies, indicating that the misappropriation of firm resources by controlling 
shareholders appear to dominate the agency problem. The finding also indicates that the insights from the literature on family firms in both the U.S. and international settings cannot be generalized to controlled companies in general. In terms of economic significance, we compute the marginal effect of the CONTROL variable. Untabulated result shows that for a controlled firm that has average size, investment, and growth, the probability that the firm has above-median industry ROA is 12.63 percentage points lower than a non-controlled firm with similar characteristics. AGE and LEVERAGE, are also significant at the $95 \%$ level. The signs of their coefficients conform to our prediction. Firm age appears to have a positive impact while leverage appears to hurt firm financial performance. SIZE, is positive and significant at the 99\% level, consistent with results documented by prior studies. The other three control variables, INVESTMENT, GROWTH, and DIVIDEND, are insignificant at the $90 \%$ level even though they have the predicted signs. Likelihood Ratio test in table 7 and Hosmer and Lemeshow Goodness of Fit test in table 6 consistently show that we can reject the null hypothesis at 5\% level. All tests show the validity of our probit regression model.

Table 5. Controlled companies and financial performance

\begin{tabular}{|c|c|c|}
\hline 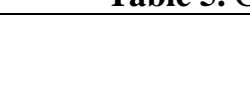 & $\begin{array}{c}\text { (1) } \\
\text { ROA }\end{array}$ & $\begin{array}{c}(2) \\
\text { ROA }\end{array}$ \\
\hline CONTROL & & $\begin{array}{c}-0.320^{* *} \\
(-2.11)\end{array}$ \\
\hline SIZE & $\begin{array}{c}0.176^{* * *} \\
(5.42)\end{array}$ & $\begin{array}{c}0.189^{* * *} \\
(5.68)\end{array}$ \\
\hline INVESTMENT & $\begin{array}{l}-0.200 \\
(-1.45)\end{array}$ & $\begin{array}{l}-0.212 \\
(-1.51)\end{array}$ \\
\hline GROWTH & $\begin{array}{l}-0.0293 \\
(-0.42)\end{array}$ & $\begin{array}{l}-0.0201 \\
(-0.29)\end{array}$ \\
\hline DIVIDEND & $\begin{array}{l}0.0777 \\
(0.19)\end{array}$ & $\begin{array}{c}0.0454 \\
(0.11)\end{array}$ \\
\hline AGE & $\begin{array}{l}0.153^{* * *} \\
(2.01)\end{array}$ & $\begin{array}{c}0.154^{* *} \\
(2.01)\end{array}$ \\
\hline LEVERAGE & $\begin{array}{c}-0.615^{* * *} \\
(-2.86)\end{array}$ & $\begin{array}{c}-0.511^{* *} \\
(-2.37)\end{array}$ \\
\hline
\end{tabular}




\begin{tabular}{|c|c|c|}
\hline & $\begin{array}{c}\text { (1) } \\
\text { ROA }\end{array}$ & $\begin{array}{c}(2) \\
\text { ROA }\end{array}$ \\
\hline cons & $\begin{array}{c}-1.253^{* * *} \\
(-4.04)\end{array}$ & $\begin{array}{c}-1.209^{* * *} \\
(-3.86)\end{array}$ \\
\hline $\begin{array}{l}N \\
\text { pseudo } R^{2}\end{array}$ & $\begin{array}{c}351 \\
0.126\end{array}$ & $\begin{array}{c}351 \\
0.136\end{array}$ \\
\hline$*, * *$, and $* * *$ indicates significant level at $10 \%, 5 \%$ and $1 \%$ respectively & \multicolumn{2}{|c|}{ Table 7. Hosmer and Lemeshow goodness-of-fit } \\
\hline \multicolumn{3}{|c|}{ Testing Null Hypothesis: The fit of the model is relatively good } \\
\hline Chi-Square & $\mathrm{DF}$ & p-value* \\
\hline 8.86 & 8 & 0.355 \\
\hline
\end{tabular}

\section{Conclusions}

In this study, we examine the financial performance of controlled companies. Controlled companies represent a group of firms with a unique structure that one party controls a majority of shares and can opt for several exemptions from the major stock exchanges' board independence requirements. Despite the growth in the market capitalization of these firms, few studies investigate how these controlled companies perform. Our findings suggest that controlled companies are underperforming compared to non-controlled companies. In particular, the Return on Assets (ROA) of controlled companies is significantly lower than non-controlled companies in our sample. A key implication of our finding is that investors should be cautious when investing in controlled companies, given the economic significance of being a control company documented in this study.

Due to data limitations, the literature on controlled company is scarce. We collect the group of controlled companies in the US by keyword search and manual verification for the year 2014. To the best of our knowledge, we are the first to collect the group of controlled companies in the US and we are among the first to study how firm performs under the type II agency problem (Pantzalis et al., 1998). We contribute to the stream of literature on how ownership structure (e.g., familycontrolled firms) affects firm performance (Anderson \& Reeb, 2003; Ahmed \& Bhuyan, 2020). Consistent with the findings from family-controlled firms, we show that ownership structure affects firm performance. Our study sheds light on the important role of controlled companies in the US capital market. Further study could investigate other aspects of controlled firms, such as investment efficiency (Cheng et al., 2020), earnings quality (e.g., Klein, 2002; Wang, 2006), etc. Our study also 
adds to recent literature about auditor choices and the principal-principal agency conflict in public firms (e.g., Ben Ali et al., 2020).

\section{References}

Ahmed, R. \& Bhuyan, R. (2020) "Capital structure and firm performance in Australian service sector firms: A panel data analysis", Journal of Risk and Financial Management, vol. 13(9): 214-214

Ali, A., Chen, T. \& Radhakrishnan, S. (2007) "Corporate disclosures by family firms", Journal of Accounting and Economics, vol. 44 (1): 238-286

Altman, E. I. (2013) "Predicting financial distress of companies: revisiting the Zscore and ZETA ${ }^{\circledR}$ models", In Handbook of research methods and applications in empirical finance, Edward Elgar Publishing

Anderson, R. C., Mansi, S. A. \& Reeb, D. M. (2003) "Founding family ownership and the agency cost of debt", Journal of Financial Economics, vol. 68(2): 263-285

Andres, C. (2008) "Large shareholders and firm performance - An empirical examination of founding-family ownership", Journal of Corporate Finance, vol. 14(4): 431-445

Armstrong, C. S., Core J. E. \& Guay, W. R. (2014) "Do independent directors cause improvements in firm transparency?", Journal of Financial Economics, vol. 113 (3): 383-403

Ali B., C., Boubaker, S. \& Magnan, M. (2020) "Auditors and the principal-principal agency conflict in family-controlled firms", Auditing: A Journal of Practice, in press

Capon, N., Farley, J. U. \& Hoenig, S. (2011) "Determinants of financial performance ", Management Science, vol. 36(10):1143-1159

Chen, S., Chen X. \& Cheng Q.(2008) "Do family firms provide more or less voluntary disclosure?", Journal of Accounting Research, vol. 46 (3): 499-536

Cheng, Q. (2014) "Family firm research - a review", China Journal of Accounting Research,vol. 7(3):149-163

Cheng, X., Mpundu, H. \& Wan, H. (2020) "Investment efficiency: Dual-class vs. Single-class firms", Global Finance Journal, vol. 45: 100477

Cremers, K. J. M., Litov, L. P. \& Sepe, S. M. (2017) "Staggered boards and longterm firm value, revisited", Journal of Financial Economics, vol. 126(2): 422444

Fan, J. P. H., \& Wong, T.J. (2002) "Corporate ownership structure and the informativeness of accounting earnings in East Asia, "Journal of Accounting and Economics", vol. 33(3): 401-425

Francis, J., Schipper, K. \& Vincent, L. (2005) "Earnings and dividend informativeness when cash flow rights are separated from voting rights", Journal of Accounting and Economics, vol. 39 (2): 329-360 
Hermalin, B. E. \& Weisbach, M.S. (1991) "The effects of board composition and direct incentives on firm performance", Financial Management, vol. 20 (4): 101-112

IRRC Institute (2012) “Controlled companies in the Standard \& Poor's 1500: A Ten Year Performance and Risk Review", IIRC Institute

IRRC Institute (2016) "Controlled companies in the Standard \& Poor's 1500: A follow-up review of performance \& risk", available online at https://irrcinstitute.org/wp-content/uploads/2016/03/Controlled-CompaniesIRRCI-2015-FINAL-3-16-16.pdf

Isakov, D. \& Weisskopf, J. P. (2014) "Are founding families special blockholders? An investigation of controlling shareholder influence on firm performance", Journal of Banking and Finance, vol. 41(1): 1-16.

Jensen, M. C. (1988) "Takeovers: Their causes and consequences", Journal of Economics Perspectives, vol. 2(1): 21-48

Kamonjoh, E. (2016) "Controlled companies in the Standard \& Poor's 1500", Institutional Shareholder Service, available online at https://www.issgovernance.com/library/controlled-companies-standardpoors-1500-follow-review-performance-risk/ (Retrieved October 2020)

Klein, A. (2002) "Audit committee, board of director characteristics, and earnings management", Journal of Accounting and Economics, vol. 33 (3): 375-400

Lin, C., Ma Y., Malatesta P. \& Xuan Y. (2011) "Ownership structure and the cost of corporate borrowing" Journal of Financial Economics, vol. 100 (1): 1-23

McGuire, S. T., Wang D. \& Wilson, R. J. (2014) "Dual class ownership and tax avoidance", The Accounting Review, vol. 89 (4): 1487-1516

Miller, D. et al. (2007) "Are family firms really superior performers?", Journal of Corporate Finance, vol.13(5): 829-858

Opler, T. \& Titman, S. (1994) "Financial distress and corporate performance", Journal of Finance, vol. 49(3): 1015-1040

Pantzalis, C., Kim, C. F. \& Kim, S. (1998) "Market valuation and equity ownership structure: the case of agency conflict regimes", Review of Quantitative Finance and Accounting, vol. 11(3): 249-268.

Roberts, P. W. \& Dowling, G. R. (2002) "Corporate reputation and sustained superior financial performance", Strategic Management Journal, vol. 23(12): 1077-1093

Sarbanes-Oxley Act (2002) Sarbanes-Oxley Act of 2002, Washington, DC: Government Printing Office. Public Law 107-204, 116 Stat 745.

Srinidhi, B. N., He S. \& Firth, M. (2014) "The effect of governance on specialist auditor choice and audit fees in US family firms", The Accounting Review, vol. 89 (6): 2297-2329

Villalongaa, B. \& Amitb, R. (2006) "How do family ownership, control and management affect firm value?", Journal of Financial Economics, vol. 80(2): $385-417$

Wang, D. (2006) "Founding family ownership and earnings quality", Journal of Accounting Research, vol. 44 (3): 619-656. 


\section{Appendix A}

\begin{tabular}{|r|r|r|c|c|}
\hline CIK & SIC & DATE & $\begin{array}{c}\text { FIL } \\
\text { E }\end{array}$ & SEC LINK of Aramark \\
\hline 158450 & 581 & $12 / 31 / 201$ & DEF & http://www.sec.gov/Archives/edgar/data/1584509/0001584 \\
9 & 2 & 4 & 14A & 509-14-000182-index.html \\
\hline
\end{tabular}

\section{Controlled Company Exception}

Certain stockholders beneficially own a majority of the voting power of all outstanding shares of our common stock. Under the NYSE corporate governance standards, a company of which more than $50 \%$ of the voting power is held by an individual, group or another company is a "controlled company" and may elect not to comply with certain corporate governance standards, including (1) the requirement that a majority of the board of directors consist of independent directors, (2) the requirement that we have a compensation committee that is composed entirely of independent directors with a written charter addressing the committee's purpose and responsibilities, (3) the requirement that we have a nominating and corporate governance committee that is composed entirely of independent directors with a written charter addressing the committee's purpose and responsibilities and (4) the requirement for an annual performance evaluation of the nominating and corporate governance and compensation committees. We utilize certain of these exemptions and have not determined that we have a majority of independent directors on the Board; and have not determined that we have a nominating and corporate governance committee or a compensation committee that is composed entirely of independent directors. Accordingly, you do not have the same protections afforded to stockholders of companies that are subject to all of the NYSE corporate governance requirements. In the event that we cease to be a "controlled company," we will be required to comply with these provisions within the transition periods specified in the NYSE corporate governance rules.

\begin{tabular}{|l|l|l|l|}
\hline Variable Description \\
\hline Variable Name & Definition and Units of Measure & Data Source & $\begin{array}{l}\text { Expected } \\
\text { sign }\end{array}$ \\
\hline CONTROL & $\begin{array}{l}\text { A binary variable, =1 if company "i” is a } \\
\text { controlled company, 0 if not. }\end{array}$ & Sec.gov & + \\
\hline SIZE & $\begin{array}{l}\text { Natural logarithm of total assets (in millions) } \\
\text { for company "i” }\end{array}$ & Compustat & + \\
\hline INVESTMENT & $\begin{array}{l}\text { Capital expenditure scaled by net sales (in } \\
\text { millions) for company "i” }\end{array}$ & Compustat & - \\
\hline
\end{tabular}




\begin{tabular}{|c|c|c|c|}
\hline \multicolumn{4}{|c|}{ Variable Description } \\
\hline GROWTH & $\begin{array}{l}\text { Percentage change in net sales in one year for } \\
\text { company " } i \text { " }\end{array}$ & r Compustat & ? \\
\hline DIVIDEND & $\begin{array}{l}\text { Dividends paid to shareholders during the } \\
\text { year scaled by book value of equity (in } \\
\text { millions) for company "i" }\end{array}$ & \begin{tabular}{l|l}
$\mathrm{e}$ & \\
Compustat \\
\end{tabular} & + \\
\hline AGE & $\begin{array}{l}\text { Natural logarithm of the age of company "i", } \\
\text { computed by subtracting the established year } \\
\text { of company "i" from the current year. }\end{array}$ & 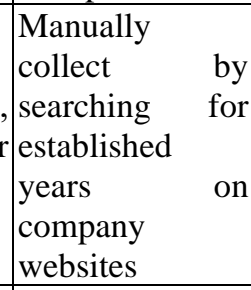 & $\mathrm{y}$ \\
\hline LEVERAGE & $\begin{array}{l}\text { Total debt divided by total assets (in } \\
\text { millions) for company " } \mathrm{i} \text { " in the current year. }\end{array}$ & Compustat & \\
\hline ROA & $\begin{array}{l}\text { A binary variable, }=1 \text { if company "i" has } \\
\text { ROA (Return on Assets) equal or greater } \\
\text { than its industry median ROA, } 0 \text { if not. ROA } \\
\text { is computed by taking income before } \\
\text { extraordinary items divided by total assets } \\
\text { (in millions), }\end{array}$ & \begin{tabular}{|l|l} 
& \\
& \\
& \\
& \\
&
\end{tabular} & + \\
\hline
\end{tabular}

${ }^{1}$ Blockholder is a shareholder that owns a large amount of a company's shares or bonds.

${ }^{2}$ Family-controlled firms are firms that have a group of family member hold a significant percentage of voting power.

${ }^{3}$ See the disclosure requirements of Instruction 1 to Item 407(a) of Regulation S-K.

${ }^{4}$ https://www.sec.gov/Archives/edgar/data/1326801/000132680118000009/fb-

12312017x10k.htm\#s34A33CD54DD3535D884B7A0E692A9046

${ }^{5}$ Institutional investors refers to mutual or pension funds and investment firms owning a large amount of shares in a company.

${ }^{6}$ There are about five thousands non-controlled listed companies in Compustat North America database in 2014. The regression model does not perform well with a binary variable that has fewer than $20 \%$ of all observations taking on one value.

${ }^{7}$ Results using raw return on assets yield similar insights.

${ }^{8} 720$ is the size of total assets in millions, derived from taking exponential of the mean value of the SIZE variable 6.16 .

${ }^{9}$ Since the variable AGE is natural logarithm of firm age, the mean number $3.19=\ln ($ age $)$. Thus, the average firm age in the sample $=\mathrm{e}^{3.19}=27.3$. 